\title{
Evaluation of Quantitative and Qualitative Attributes of Forage Sorghum Irrigated with Saline Water
}

\section{Aftab Ahmad Sheikh', Khalil Ahmed ${ }^{1 *}$, Belqees Akhter', Ghulam Qadir ${ }^{1}$, Muhammad Qaisar Nawaz ${ }^{1}$, Hafeezullah Rafa ${ }^{1}$, Abdul Wakeel ${ }^{1}$, Abdul Manan Saeed ${ }^{2}$}

\section{${ }^{1}$ Soil Salinity Research Institute Pindi Bhattian, Pakistan; ${ }^{2}$ Soil and water testing laboratory for research Gujranwala, Pakistan.}

Abstract | High population growth rates, shortage of fresh water, and threat of climatic change are major constrains for expansion of irrigated agriculture in the country. In this scenario, use of underground saline water for crop production with acceptable economic yield is a viable management strategy. Therefore, a lysimeter study was conducted to evaluate the effects of saline water on quality and quantity of forage sorghum (Sorghum bicolor L.). Forage sorghum was sown in cemented blocks and five increasing levels of saline water $\left(0.30,4,6,8\right.$ and $\left.10 \mathrm{dS} \mathrm{m} \mathrm{m}^{-1}\right)$ were used to irrigate the crop. Data regarding the plant height, fresh/dry fodder yield, nitrogen free extracts (NFE), crude fat, crude protein, crude fiber, phosphorus, and calcium contents were envaulted at the physiological maturity of crop, four months after the sowing of crop. Results revealed that water salinity adversely affected the quantitative and qualitative attributes of sorghum crop and negative effects were more pronounced with higher level of salinity $\mathrm{EC}_{\mathrm{iw}}(10$

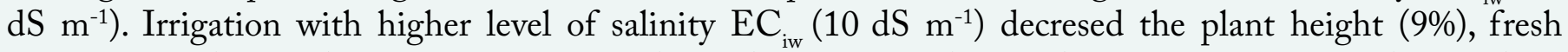
fodder yield (16.21\%), dry biomass yield (7.86\%), crude fat (25.40\%) and crude protein (17.94\%) as compared to control. Results also showed that water salinity of $4 \mathrm{dS} \mathrm{m} \mathrm{m}^{-1}$ did not decreased most of the studied parameters as compared with control. Therefore. it was concluded that forage sorghum can grow successfully without any significant loss in yield and acceptable fodder quality with water salinity of $4 \mathrm{dS} \mathrm{m} \mathrm{m}^{-1}$.

Received | June 22, 2021; Accepted | December 27, 2021; Published | January 12, 2022

*Correspondence | Khalil Ahmed, Soil Salinity Research Institute Pindi Bhattian, Pakistan; Email: khalilahmeduaf@gmail.com

Citation | Sheikh, A.A., K. Ahmed, B. Akhter, G. Qadir, M.Q. Nawaz, H. Rafa, A. Wakeel, A.M. Saeed. 2021. Evaluation of quantitative and qualitative attributes of forage sorghum irrigated with saline water. Pakistan Journal of Agricultural Research, 34(4): 905-912.

DOI | https://dx.doi.org/10.17582/journal.pjar/2021/34.4.905.912

Keywords | Sorghum, Quality, Yield, Saline water, Fodder

\section{Introduction}

$\mathrm{D}$ ue to continuous increase in world population and competition among industrial and agriculture sectors for fresh water, it is opined that after every 35 years, water requirement will be doubled to the present (Naeimi and Zehtabian, 2011). This situation is further expected to intensify in countries of water deficit regions like Pakistan where shortage and un reliable supply of fresh water is a major constraint for expansion of irrigated agriculture, econom- ic growth and regional development. Hence, in foreseeable future, not only land but also supply of fresh water will determine the sustainability and expansion of agricultural productivity. In Pakistan, 1.2 million tube wells are workig and unchecked exploitation of underground water has has created severe environmental problems like soil salinity (Qureshi, 2020). Therefore, knowledge of salt tolerance potential of field crops against saline water irrigation is necessary to devise practicable and feasible strategy for enhancing the productivity of agriculture system. Sorghum December 2021 | Volume 34 | Issue 4 | Page 905 
also known as jawar in Pakistan, is grown on the area 0.34 million hectare with annual production of 0.21 million ton (Habib et al., 2013). Sorghum is identified as moderately tolerant to saline areas and showed intraspecific variability of yield and quality parameters for salinity tolerance (Shakeri and Emam, 2017). It could be cultivated in saline (Saberi, 2013; Dong, 2018) and dry environments (Yan et al., 2012) as dual-purpose crop for forage and grain yield with limited water demand and low nitrogen consumption (Olanite et al., 2010; Chen et al., 2018). These advantages of sorghum are very important, especially with increased return of unit value of water (Mahfouz et al., 2015) and offer the sorghum as a good alternative silage crop as compared to maize and other legumes crops in salt-affected soils (Qu et al., 2014; Sánchez-Duarte et al., 2018). In this perspective, cultivation of sorghum crop with brackish water is a strategic option to increase the productivity of forage during the summer season and wise use of available water resources.

In a field study, Joardar et al. (2018) irrigated the sorghum crop with saline water having the $\mathrm{EC}_{\mathrm{iw}}(0.78$, 4.19, 7.18, 10.79 and $14.04 \mathrm{dS} \mathrm{m} \mathrm{m}^{-1}$ ). Results showed that number of leaves, stem diameter, and biomass yield of sorghum crop decreased linearly with increasing EC level of irrigation water. They concluded that when fresh water supply is limited, sorghum crop could be grown successfully with saline water of $10.79 \mathrm{dS} \mathrm{m}^{-1}$ in the coastal regions of Bangladesh. Igartua et al. (1995) investigated the response of one sorghum cultivar and eleven inbred lines irrigated with saline water. They observed significant genotypic responses to salinity and the traits most affected by salinized conditions were shoot dry weight, grain yield, $\mathrm{Na}, \mathrm{K}$, and $\mathrm{Ca}$ contents in leaves. Similarly, in a pot experiment, Guimaraes et al. (2019) evaluated the performance of six sorghum varieties viz. Ponta Negra, 2600-IPA, 1011-IPA, 2502-IPA, 2564-IPA, and Qualimax irrigated with brackish water of $(0,1.5$, 3.0, 6.0, and $\left.12.0 \mathrm{dS} \mathrm{m}^{-1}\right)$. They identified that 2502IPA and 1011-IPA are the most salt tolerant varieties with maximum grain yield using brackish water of $6.0 \mathrm{dS} \mathrm{m}^{-1}$ while 2600-IPA was recognized as most sensitive variety to water salinity $\left(2.75 \mathrm{dS} \mathrm{m}^{-1}\right)$ with $50 \%$ reduction in yield. Sun et al. (2014) evaluated the salinity tolerance of ten sorghum varieties (Tx7078, RTx430, BTx642, Tx2783, 1790E, Wheatland, Desert Maize, Schrock, Shallu, and Macia). All the varieties were irrigated with water salinity of $1.25,5,10$ and $17 \mathrm{dS} \mathrm{m}^{-1}$. On the basis of morphological traits (plant height, shoot dry weight, number of leaves, and number of tillers) and mineral nutrient contents of leaves $(\mathrm{Na}, \mathrm{K}, \mathrm{Ca}$, and $\mathrm{Cl})$, they categorized $1790 \mathrm{E}$, Shallu and Desert Maize as the most salt tolerant, whereas RTx430 and Schrock proved as salt sensitive varieties. Niu et al. (2012) investigated the responses of sorghum varieties (KS585, NK7829, SS304 and Sordan 79) against water salinity of $8 \mathrm{dS} \mathrm{m}$. Water salinity reduced the net photosynthetic rate, leaf transpiration and stomatal conductance. They concluded that KS585 was the most salt sensitive genotype while Sordan79 was the most salt tolerant genotype. Irrigation with salinity level of $3.0 \mathrm{dS} \mathrm{m}^{-1}$ significantly reduced the biomass yield, plant height and number of plants $\mathrm{m}^{2}$ in sorghum (Murtaza et al., 2020).

Under the above considerations, the present study was planned and conducted with the objective to evaluate the toxic effect of various levels of saline water on qualitative and quantitative attributes of forage sorghum and to determine the level of saline water which can be used to grow sorghum without any significant loss in yield and acceptable fodder quality.

\section{Materials and Methods}

A lysimeter experiment was conducted at the campus of Soil Salinity Research Institute Pindi Bhattian (altitude $184 \mathrm{~m}$, latitude $31.8950^{\circ} \mathrm{N}$ and longitude $73.2706^{\circ}$ E) from Kharif 2014 to 2015 to investigate the qualitative and quantitative attributes of sorghum fodder irrigated with saline water. Normal soil with $\mathrm{EC}_{\mathrm{e}}$ (electrical conductivity of soil extract $)=1.69 \mathrm{dS}$ $\mathrm{m}^{-1}, \mathrm{pH}_{\mathrm{s}}=$ ( $\mathrm{pH}$ of soil saturated paste) 7.97 , and SAR (sodium adsorption ratio) $=6.06$ was filled in cement ed lysimeters $(6 \times 4 \times 3 \mathrm{ft})$. During the $3^{\text {rd }}$ week of July 2014 and 2015, the forage sorghum (cv. Hegari) was sown in Completely Randomized Design (CRD) arrangement having three replications. Recommended dose of fertilizers at the rate of 60-60 NP kg ha-1 was applied in the form of urea and single super phosphate (SSP). The following treatments were tested i.e. $\mathrm{T}_{1}$ Tap water $\left(0.30 \mathrm{dS} \mathrm{m} \mathrm{m}^{-1}\right), \mathrm{T}_{2} \mathrm{EC}_{\mathrm{iw}} 4.0 \mathrm{dS} \mathrm{m} \mathrm{m}^{-1}, \mathrm{~T}_{3}$ $\mathrm{EC}_{\mathrm{iw}} 6.0 \mathrm{dS} \mathrm{m}^{-1}, \mathrm{~T}_{4} \mathrm{EC}_{\mathrm{iw}} 8.0 \mathrm{dS} \mathrm{m}{ }^{-1}, \mathrm{~T}_{5} \mathrm{EC}_{\mathrm{iw}} 10.0 \mathrm{dS}$ $\mathrm{m}^{-1}$. The lysimeter were irrigated as per crop requirement and approximately 100 liters lysimeter ${ }^{-1}$ irriga- $^{-}$ tion $^{-1}$ were given, a total of 5 irrigations were applied in each season. Weeds were control through manual hoeing. The data regarding plant height, fresh/dry fodder yield and moisture $\%$ in leaves was recorded at maturity during the $2^{\text {nd }}$ week of October 2014 and 
2015, four months after the sowing of crop. Quality parameters of sorghum fodder \{nitrogen free extracts (NFE), crude fiber, crude protein and crude fat $\}$ were determined following the procedure of AOAC (2005), while phosphorus and calcium were estimated using the methods as per Tandon (2005). Composit soil samples were collected before the start of experiment and after the harvest of crop. Collected soil samples were air dried, passed through $2 \mathrm{~mm}$ sieve and analyzed by following the methods of U.S. Salinity Laboratory Staff (1954). All the data were subjected to analysis of variance using STATISTIX 8.1 package software following the method of Steel et al. (1997). Least significant difference (LSD) test at 5\% probability level was employed to sort out significant differences among treatments means.

\section{Results and Discussion}

Effect of saline water on plant quantitave characteristics Results of two years study showed that saline water of $\mathrm{EC}_{\text {iw }}$ above $6.0 \mathrm{dSm}^{-1}$ irrigation adversely affected the growth and fodder yield of sorghum. Data about plant height (Table 1) revealed that maximum plant height $(174.3 \mathrm{~cm})$ was divulged by $\mathrm{T}_{1}\left(0.30 \mathrm{dS} \mathrm{m} \mathrm{m}^{-1}\right)$ which was similar $(P<0.05)$ with $\left(\mathrm{T}_{2}\right)$ brackish water of $4 \mathrm{dS} \mathrm{m} \mathrm{m}^{-1}$, however, further increase in water salinity exerted a noticeable negative effect on plant height. The minimum plant height of $158.6 \mathrm{~cm}$ was observed with the highest dose of salinity level $\left(10.0 \mathrm{dS} \mathrm{m} \mathrm{m}^{-1}\right)$. Similarly, in the case of fresh fodder yield maximum fodder yield ( $\left.58.48 \mathrm{t} \mathrm{ha}^{-1}\right)$ was observed in $\mathrm{T}_{2}\left(4 \mathrm{dSm}^{-}\right.$ $\left.{ }^{1}\right)$ which remained non-significant with $\mathrm{T}_{1}$ (tap water), however, further increment in water salinity adversely affected the fodder yield and highest level of salinity $10.0 \mathrm{dS} \mathrm{m} \mathrm{m}^{-1}\left(\mathrm{~T}_{5}\right)$ produced minimum fodder yield of $48.97 \mathrm{t} \mathrm{ha}^{-1}$ (Table 1). As far as dry biomass yield and moisture (\%) are concerned, the maximum dry biomass yield (11.44 $\left.\mathrm{t} \mathrm{ha}^{-1}\right)$ and moisture content $(80.49 \%)$ were observed by tap water irrigation (control) which remained insignificant with $\mathrm{T}_{2}\left(4 \mathrm{dS} \mathrm{m}^{-1}\right)$ (Table 1). While minimum dry biomass yield (10.54 t $\left.\mathrm{ha}^{-1}\right)$ and moisture $\%$ (78.48) were documented by $\mathrm{T}_{5}$ $\left(10.0 \mathrm{dS} \mathrm{m}^{-1}\right)$. Data about dry matter\% and ash\% (Table 2) showed that saline water irrigation increased the values of these attributes and maximum values of dry matter (21.77\%) and ash (11.45\%) were achieved with the highest dose of salinity $\left(\mathrm{EC}_{\mathrm{iw}} 10.0 \mathrm{dS} \mathrm{m} \mathrm{m}^{-1}\right)$. Whereas control (tap water) recorded the minimum values of dry matter (16.02\%) and ash (8.59\%). Data about minerals nutrient content (Table 2) showed that saline water negatively affected the phosphorus content of sorghum fodder and maximum phosphorus content $(0.154 \%)$ was noted in control $\left(\mathrm{T}_{1}\right)$, which was non-significant from $\mathrm{T}_{2}\left(4.0 \mathrm{dS} \mathrm{m} \mathrm{m}^{-1}\right)$. However, increasing levels of salinity decreased the phosphorus content and minimum value $(0.110 \%)$ was observed at salinity treatment of $10.0 \mathrm{dS} \mathrm{m} \mathrm{m}^{-1}$. Similarly, maximum calcium content $(0.089 \%)$ was recorded in $\mathrm{T}_{1}$ $\left(0.23 \mathrm{dS} \mathrm{m}^{-1}\right)$ which remain non-significant $(P<0.05)$ up to salinity level of $8.0 \mathrm{dS} \mathrm{m}^{-1}\left(\mathrm{~T}_{4}\right)$. While the highest dose of salinity $\left(10.0 \mathrm{dS} \mathrm{m}^{-1}\right)$ significantly reduced the calcium content and recorded the minimum value of $0.076 \%$.

Table 1: Effect of saline irrigation water on plant height, fresh fodder yield, dry biomass yield and moisture contents of sorghum fodder (average of two season).

Salinity levels of Plant Fresh fodder Dry bio- Moisture irrigation water height Yield $\left(\mathrm{tha}^{-1}\right)$ mass yield (\%)

$\begin{array}{lll}\left(\mathrm{dS} \mathrm{m}^{-1}\right) & (\mathrm{cm}) & \left(\mathrm{t} \mathrm{ha}^{-1}\right)\end{array}$

$\begin{array}{lllll}\mathrm{T}_{1}=0.30 & 174.3 \mathrm{a} & 58.45 \mathrm{a} & 11.44 \mathrm{a} & 80.49 \mathrm{a}\end{array}$

$\mathrm{T}_{2}=4.0 \quad 173.9$ a $58.48 \mathrm{a} \quad 11.41 \mathrm{ab} \quad 80.42 \mathrm{a}$

$\mathrm{T}_{3}=6.0 \quad 170.8 \mathrm{~b} 56.78 \mathrm{~b} \quad 11.24 \mathrm{~b} \quad 80.20 \mathrm{~b}$

$\begin{array}{llll}\mathrm{T}_{4}=8.0 & 164.7 \mathrm{c} 53.82 \mathrm{c} & 11.03 \mathrm{c} & 79.50 \mathrm{c}\end{array}$

$\mathrm{T}_{5}=10.0 \quad 158.6 \mathrm{~d} 48.97 \mathrm{~d} \quad 10.54 \mathrm{~d} \quad 78.48 \mathrm{~d}$

$\begin{array}{lllll}\text { LSD } & 2.4600 & 1.3975 & 0.1975 & 0.1908\end{array}$

Table 2: Effect of saline irrigation water on dry matter, ash, phosphorus, and calcium contents of sorghum fodder (average of two season).

\begin{tabular}{|c|c|c|c|c|}
\hline $\begin{array}{l}\text { Salinity levels of } \\
\text { irrigation water } \\
\left(\mathrm{dS} \mathrm{m}^{-1}\right)\end{array}$ & $\begin{array}{l}\text { Dry matter } \\
\text { (\%) }\end{array}$ & $\begin{array}{l}\text { Ash } \\
\text { (\%) }\end{array}$ & $\begin{array}{l}\text { Phosphorus } \\
\text { (\%) }\end{array}$ & $\begin{array}{l}\text { Calcium } \\
\text { (\%) }\end{array}$ \\
\hline $\mathrm{T}_{1}=0.30$ & $16.02 \mathrm{c}$ & $8.59 \mathrm{~b}$ & $0.154 \mathrm{a}$ & $0.089 \mathrm{a}$ \\
\hline $\mathrm{T}_{2}=4.0$ & $17.71 \mathrm{bc}$ & $8.43 \mathrm{~b}$ & $0.146 \mathrm{a}$ & $0.085 \mathrm{a}$ \\
\hline $\mathrm{T}_{3}=6.0$ & $18.39 \mathrm{abc}$ & $8.88 \mathrm{~b}$ & $0.118 \mathrm{~b}$ & $0.081 \mathrm{ab}$ \\
\hline $\mathrm{T}_{4}=8.0$ & $20.42 \mathrm{ab}$ & $9.27 \mathrm{~b}$ & $0.116 \mathrm{~b}$ & $0.081 \mathrm{ab}$ \\
\hline $\mathrm{T}_{5}=10.0$ & $21.77 \mathrm{a}$ & $11.45 \mathrm{a}$ & $0.110 \mathrm{~b}$ & $0.076 \mathrm{~b}$ \\
\hline LSD & 3.638 & 1.547 & 0.021 & 0.007 \\
\hline
\end{tabular}

Effect of saline water on plant qualitative characteristics Data regarding the forage quality (Table 3 ) indices revealed that salinity level of $4.0 \mathrm{dS} \mathrm{m} \mathrm{m}^{-1}$ did not influenced the crude fat and crude protein while further increase in water salinity negatively affected these forage qualities. Maximum value of crude fat (3.07\%) and crude protein $(9.92 \%)$ were observed in $T_{1}(0.23$ $\left.\mathrm{dS} \mathrm{m} \mathrm{m}^{-1}\right)$ which remained non-significant with $\mathrm{T}_{2}(4.0$ $\mathrm{dS} \mathrm{m} \mathrm{m}^{-1}$ ). While increasing doses of water salinity diminished the values of these qualities and minimum 
values of $2.29 \%$ and $8.14 \%$ were recorded for crude fat and crude protein respectively for $\mathrm{T}_{5}\left(10.0 \mathrm{dS} \mathrm{m}^{-1}\right)$. As far as crude fiber and NFE were concerned, saline water did not produce any significant effect in these quality parameters and all the treatments statistically $(P<0.05)$ remained insignificant from each other.

Table 3: Effect of saline irrigation water on crude fat, crude protein, crude fiber and NFE of sorghum fodder (average of two season).

$\begin{array}{lllll}\begin{array}{l}\text { Salinity levels of } \\ \text { irrigation water } \\ \left(\mathbf{d S m}^{-1}\right)\end{array} & \begin{array}{l}\text { Crude fat } \\ (\mathbf{\%})\end{array} & \begin{array}{l}\text { Crude } \\ \text { Protein } \\ (\%)\end{array} & \begin{array}{l}\text { Crude fiber } \\ \mathbf{( \% )}\end{array} & \begin{array}{l}\text { NFE } \\ (\mathbf{\%})\end{array} \\ \mathrm{T}_{1}=0.30 & 3.07 \mathrm{a} & 9.92 \mathrm{a} & 27.58 \mathrm{a} & 49.11 \mathrm{a} \\ \mathrm{T}_{2}=4.0 & 3.05 \mathrm{a} & 9.86 \mathrm{a} & 28.34 \mathrm{a} & 49.41 \mathrm{a} \\ \mathrm{T}_{3}=6.0 & 2.93 \mathrm{~b} & 8.46 \mathrm{~b} & 28.71 \mathrm{a} & 50.09 \mathrm{a} \\ \mathrm{T}_{4}=8.0 & 2.36 \mathrm{~b} & 8.37 \mathrm{~b} & 28.73 \mathrm{a} & 50.67 \mathrm{a} \\ \mathrm{T}_{5}=10.0 & 2.29 \mathrm{~b} & 8.14 \mathrm{~b} & 29.72 \mathrm{a} & 52.60 \mathrm{a} \\ \mathrm{LSD} & 0.433 & 0.988 & 2.3411 & 5.0561\end{array}$

\section{Effect of saline water on soil properties}

Data regarding the soil chemical properties showed that saline water significantly increased the $\mathrm{pH}_{\mathrm{s}}$, SAR and $\mathrm{EC}_{\mathrm{e}}$ of the soil (Table 4). At the end of study, maximum $\mathrm{pH}_{\mathrm{s}}$ value of 8.11 was observed with higher level of salinity $\left(\mathrm{EC}_{\mathrm{iw}} 10.0 \mathrm{dS} \mathrm{\textrm {m } ^ { - 1 }}\right)$ with an increased of $1.75 \%$ over its initial value. While minimum increase of $0.37 \%$ over its initial value in $\mathrm{pH}_{\mathrm{s}}$ was noted in $\mathrm{T}_{1}\left(\mathrm{EC}_{\mathrm{iw}} 0.30 \mathrm{dS} \mathrm{\textrm {m } ^ { - 1 }}\right)$. Irrigation with saline water had pronounced effect on final electrical conductivity of soil and increased linearly with increasing levels of water salinity. Maximum value of $\mathrm{EC}_{\mathrm{e}}$ (6.26) with increase of $270.41 \%$ over its initial value was observed where saline water of $10.0 \mathrm{dS} \mathrm{m}-1$ was used continuously for two years. On the other hand, minimum value of $\mathrm{EC}_{\mathrm{e}}$ (1.71) with an increase of $1.18 \%$ over its initial value was documented in $\mathrm{T}_{1}$. Likewise, in the case of soil SAR, $\mathrm{T}_{5}\left(\mathrm{EC}_{\mathrm{iw}} 10.0 \mathrm{dS}\right.$ $\mathrm{m}^{-1}$ ) recorded maximum value (7.28) of SAR with an increase of $20.13 \%$ as compare to initial value of SAR at the start of study. While minimum value (6.05) of
SAR was divulged in $\mathrm{T}_{1}$ (control) with an increase of $0.16 \%$ over its initial value.

The continuous expanding population, increasing demand of water for industrial, domestic use and agriculture sector are the major factors of water shortage and this situation is further exacerbated in developing countries like Pakistan which are also facing the threat of climatic change. For the sustainable irrigated agriculture, reliance on underground saline water seems inevitable. In this perspective, use of such agronomical crops that can produce the economic growth and yield with saline water irrigation is a very effective management practice. This approach could be the key to future agricultural and play a vital role in social wealth of the areas where underground water is saline and its disposal options are limited. In our study we used the sorghum crop which is reported as fairly tolerant to salinity (Sui et al., 2015). The objective of the study was to evaluate the effect of different salinity levels of irrigation water on the yield and quality parameters of forage sorghum. Results reveled that increasing levels of water salinity significantly reduced the plant height that could be attributed to osmotic effect of salt stress which inhibits the uptake of essential mineral nutrients required for necessary plant growth and development (Rady et al., 2015; Semida et al., 2017). Data also indicated a negative correlation between fresh/dry fodder yield and higher salinity levels. It is well established fact that salt stress reduces the productivity of sorghum crop (Yang et al., 2018). This reduction in biomass yield due to water salinity could be explained by toxic concentration of ions in leaves (Munns, 2002), inhibition of water uptake by the roots because of high osmotic pressure of brackish water resulting reduced plant growth and development and ultimately the final yield is decreased. It also reflects the reduced carbon gain and enhanced metabolic energy cost which could be corelated to adaptation to saline environment (Netondo et al., 2004). Our results are also strengthen by earlier findings that saline water of $10 \mathrm{dS} \mathrm{m} \mathrm{m}^{-1}$ may reduce the production

Table 4: Effect of saline irrigation on soil $p H, E G$, SAR of soil at the end of study.

\begin{tabular}{lllllll}
$\begin{array}{l}\text { Salinity levels of irrigation water } \\
\left(\mathbf{d S} \mathbf{~ m}^{-1}\right)\end{array}$ & $\mathbf{p}_{\mathbf{H}} \mathbf{s}$ & $\begin{array}{l}\text { \% increase over } \\
\text { initial value }\end{array}$ & $\begin{array}{l}\mathbf{E C}_{\mathbf{e}}\left(\mathbf{d S m}^{-1}\right) \\
\text { \% increase over initial SAR } \\
\text { value }\end{array}$ & $\begin{array}{l}\text { \% increase over initial } \\
\text { value }\end{array}$ \\
$\mathrm{T}_{1}=0.30$ & 8.00 & 0.37 & 1.71 & 1.18 & 6.05 & 0.16 \\
$\mathrm{~T}_{2}=4.0$ & 8.03 & 0.75 & 2.69 & 59.17 & 6.36 & 4.95 \\
$\mathrm{~T}_{3}=6.0$ & 8.05 & 1.00 & 3.95 & 133.72 & 6.68 & 10.23 \\
$\mathrm{~T}_{4}=8.0$ & 8.10 & 1.63 & 4.90 & 189.94 & 7.09 & 16.99 \\
$\mathrm{~T}_{5}=10.0$ & 8.11 & 1.75 & 6.26 & 270.41 & 7.28 & 20.13 \\
\hline
\end{tabular}

December 2021 | Volume 34 | Issue 4 | Page 908 
of sorghum crop up to 52\% (Sun et al., 2014). Similarly, in another study, Shakeri and Emam (2017) reported a reduction of up to $66 \%$ in sorghum yield with saline water irrigation having $\mathrm{EC}$ of $12 \mathrm{dS} \mathrm{m}^{-1}$. Our results are reinforced by the previous findings of Omer and Abdelwahab (2016) and Guimaraes et al. (2019) that saline water reduced the fodder yield of sorghum crop. Results also revealed that dry matter\% and ash\% increased with increasing the levels of salinity which may be attributed to low moisture contents in leaves (Table 1). Saline environment inhibits the uptake of water by roots due to more negative water potential of saline soils (Tigabu et al., 2013).

An inverse relationship between minerals content $(\mathrm{P}$ and $\mathrm{Ca})$ and higher doses of saline water was also observed. This could be justified by the fact that salt stress damage the mechanisms that control the intracellular P concentration (Johnson, 1981). In addition, at higher salt concentration, mineral nutrients are not absorb effeciently by the roots and percentage of mineral nutrients will remain low (Devline et al., 1993). Reduced contents of minerals in sorghum leaves in saline environment was also reported by Netondo et al. (2004) and Al-amoudi and Afaf (2012) that supports the current findings.

Among the quality parameters of any forage crop, crude protein and fat have prime importance in evaluating the forage quality because they play direct role in improving the health of animals (Soni et al., 2016). In current study, results showed that saline water adversely affected the crude fat and protein contents. Possible reason of this low crude fat and protein with saline water irrigation may be that salt stress induced a nutritional imbalance in plants. Uptake of minerals nutrients like $\mathrm{N}, \mathrm{P}$ and $\mathrm{Ca}$ reduced under the salt stress (Qadar, 2009; Irshad et al., 2009). As reported by Bavei et al. (2011) salt stress decreases the synthesis of amino acid which in turn reduces the protein contents. Phosphorus is integral constituent of ATP, the energy carrier involved in different metabolic processes and protein synthesis (Abd E1-Lattief, 2011). Salt stress in rhizosphere render the conditions which reduced the uptake of nitrogen and phosphorus and it ultimately decreased the protein synthesis.

Fiber content in a forage is also an important quality index because high quality forage has low content of crude fiber which make it digestible (Keshavarz et al., 2012). In our finding crude fiber content and NFE\% increased with saline water irrigation but statistically remain non-significant in all treatments. According to Ben-Ghedalia et al. (2001) fiber content responded positively with increasing level of saline water. Similarly, Keshavarz et al. (2012) stated that cell wall becomes more rigid and hard due to accumulation of salts that lowered the quality and digestibility of a forage crop. The deteriorated quantitative and qualitative attributes of sorghum crop with the use of saline water was also stated by different researchers (Abd El-Mageed et al., 2018; Guimaraes et al., 2019; Murtaza et al., 2020; Calone et al., 2020) which strengthen the findings of current study.

Soil analysis data after the harvest of $2^{\text {nd }}$ sorghum crop revealed that saline water irrigation significantly increased the soil $\mathrm{EC}_{\mathrm{e}}, \mathrm{SAR}$ and $\mathrm{pH}_{\mathrm{s}}$. Concentration of soluble salts in soil $\left(\mathrm{EC}_{\mathrm{e}}\right)$ increased linearly with increasing levels of salinity and the adverse impact was more pronounced with irrigation of saline water of $10.0 \mathrm{dS} \mathrm{m} \mathrm{m}^{-1}$. A plausible reason for this increased electrical conductivity and soil reaction $\left(\mathrm{pH}_{\mathrm{s}}\right)$ and SAR was the buildup of soluble salts in soil due to continous use of saline water (Murtaza et al., 2009; Iqbal et al., 2014). Comparable results are posited by Saqib et al. (2018) that soil salinity and sodicity increased progressively with saline water irrigation.

\section{Conclusions and Recommendations}

Constant supply of fresh water resources is expected to decrease in foreseen future due to climate changes and the situation may become more worse in countries of arid to semi-arid regions, including Pakistan. High population growth rates required the expansion in irrigated agriculture, therefore to fulfill the gap between increasing water demand and water availability, use of underground saline water with minimize side effects on crop growth and quality will be the effective and wiser management strategy. From the above results it can be concluded that forage sorghum can grow successfully without any significant loss in yield and quality in area having water salinity of $4 \mathrm{dS} \mathrm{m}$.

\section{Novelty Statement}

Forage sorghum can grow successfully without any significant loss in yield and quality in area having water salinity of $4 \mathrm{dS} \mathrm{m} \mathrm{m}^{-1}$. 
Author's Contribution

Aftab Ahmad Sheikh: Wrote the manuscript, review the literature and provided technical input at every step.

Khalil Ahmed and Ghulam Qadir: Conceived the idea and conducted the study for two years.

Belqees Akhter and Hafeezullah Rafa: Wrote the abstract and materials and methods.

Muhammad Qaisar Nawaz, Abdul Wakeel and Abdul Manan Saeed: Did the data collection and statistical analysis.

\section{Conflict of interest}

The authors have declared no conflict of interest.

\section{References}

Abd El-Lattief,E.A.2011. Growth and fodder yield of forage pearl millet in newly cultivated land as affected by date of planting and integrated use of mineral and organic fertilizers. Asian J. Crop Sci., 3(1): 35-42. https://doi.org/10.3923/ ajcs.2011.35.42

Abd El-Mageed, T.A., S.A. Mohammed, I.M. El-Samnoudi and A.A.M. Ibrahirm. 2018. Interactive effects of soil salinity and water table depth on soil properties and sorghum (Sorghum bicolor L. Moench) production. Arch. Agric. Environ. Sci., 3(1): 15-24. https://doi.or $\mathrm{g} / 10.26832 / 24566632.2018 .030102$

Al-amoudi, O.A. and A.R. Afaf. 2012. Effect of nutrient cations to improving salinity tolerance responses in sorghum bicolor L. Int. J. life Sci. Pharma Res., 2(2): 77-87.

AOAC. 2005. Official Methods of Analysis. 18th edition. Association of Official Analytical Chemists Arlington, VA, USA.

Bavei, V., B. Shiran, M. Khodambashi and A. Ranjbar. 2011. Protein electrophoretic profiles and physiochemical indicators of salinity tolerance in Sorghum bicolor L. Afr. J. Biotechnol., 10 (14): 2683-2697. https://doi. org/10.5897/AJB09.754

Ben-Ghedalia, D., R. Solomon, J. Miron, E. Yosef, Z. Zomberg, E. Zukerman, E. Greenberg and T. Kipnis. 2001. Effect of water salinity on the composition and in vitro digestibility of winterannual rye grass grown in the Arawa desert. Anim. Feed Sci. Tech., 91: 139-147. https://doi. org/10.1016/S0377-8401(01)00218-8
Calone, R. R. Sanoubar, C. Lambertini, M. Speranza, L.V. Antisari, G. Vianello and L. Barbanti. 2020. Salt Tolerance and $\mathrm{Na}$ allocation in sorghum bicolor under variable soil and water salinity. Plants, 9: 1-20. https:// doi.org/10.3390/plants9050561

Chen, L., X. Yuan, J. Li, Z. Dong and T. Shao. 2018. Effects of applying oil extracted microalgae on the fermentation quality, feed-nutritive value and aerobic stability of ensiled sweet sorghum. J. Sci. Food Agric., 98: 4462-4470. https://doi. org/10.1002/jsfa.8970

Devline, R.M and F.H. Wisman. 1993. Plant Physiology, $4^{\text {th }}$ edition. AlDar Alarabia, Cairo, Egypt.

Dong, H.R. 2018. Research progress on plant tolerance to soil salinity and alkalinity in sorghum. J. Integrative Agri., 17(4): 739$746 . \quad$ https://doi.org/10.1016/S20953119(17)61728-3

Guimaraes, M.J.M., L.S. Welson, A.R. de Oliveira, G.G.L. de Araujo, E.F. Silva and L.G. Willadino. 2019. Biometrics and grain yield of sorghum varieties irrigated with salt water. R. Bras. Eng. Agric. Ambiental, 4: 285-290. https://doi.org/10.1590/1807-1929/agriambi. v23n4p285-290

Habib, N., A. Tahir and Q. Ain. 2013. Current situation and future outlook of sorghum area and production in Pakistan. Asian J. Agri. Rural Dev., 3(5): 283-289.

Igartua, E., M.P. Garcia and J.M. Lasa. 1995. Field responses of grain sorghum to a salinity gradient. Field Crops Res., 42: 15-25. https:// doi.org/10.1016/0378-4290(95)00018-L

Iqbal, J., S. Kanwal, S. Hussain, T. Aziz and M.A. Maqsood. 2014. Zinc application improves maize performance through ionic homeostasis and ameliorating devastating effects of brackish water. Int. J. Agric. Biol., 16: 383-388.

Irshad, M., A. Egrinya, R. Khattak and K.Abdullah. 2009. Influence of nitrogen and saline water on the growth and partitioning of mineral content in maize. J. Plant Nutr. 32: 458-469. https:// doi.org/10.1080/01904160802660768

Joardar, J.C., S.A.A. Razir, M. Islam and M.H. Kobir. 2018. Salinity impacts on experimental fodder sorghum production. SAARC J. Agric., 16(1): 145-155. https://doi.org/10.3329/sja. v16i1.37430

Johnson, C.B. 1981. Physiological Processes 
Limiting Plant Productivity, $1^{\text {st }}$ edition, William Clowes, London. Greet Britain.

Keshavarz A.R., M.R. Chaichi, M.H. Asareh, M. Hashemi and A. Liaghat. 2014. Interactive effect of deficit irrigation and soil organic amendments on seed yield and flavonolignan production of milk thistle (Silybum marianum L. Gaertn.). Ind. Crops Prod., 58: 166-172. https://doi.org/10.1016/j.indcrop.2014.03.043

Mahfouz, H., A.M.M. Ali, E.A. Megawer and A.S. Mahmoud. 2015. Response of growth parameters, forage quality and yield of dualpurpose sorghum to re-growth and different levels of FYM and $n$ fertilizers in new reclaimed soil. Int. J. Curr. Microbiol. App. Sci., 4(11): 762-782.

Munns, R. 2002. Comparative physiology of salt and water stress. Plant Cell Environ., 25: 239-250. https://doi.org/10.1046/j.00168025.2001.00808.x

Murtaza, G., A. Ghafoor, G. Owens, M. Qadir and U. Kahlon. 2009. Environmental and economic benefits of saline-sodic soil reclamation using low quality water and soil amendments in conjunction with a rice-wheat cropping system. J. Agro. Crop Sci., 195: 124-36. https://doi. org/10.1111/j.1439-037X.2008.00350.x

Murtaza, G., A. Ghafoor, G. Owens, M. Qadir, U. Kahlon. 2009. Environmental and economic benefits of saline-sodic soil reclamation using low quality water and soil amendments in conjunction with a rice-wheat cropping system. J. Agro. Crop Sci., 195: 124-36. https://doi. org/10.1111/j.1439-037X.2008.00350.x

Naeimi, M. and G. Zehtabian. 2011. The review of saline water in desert management. Int. J. Environ. Sci. Dev., 2: 474-478. https://doi. org/10.7763/IJESD.2011.V2.172

Netondo, G.W.O., J. Collins and B. Erwin. 2004. Sorghum and Salinity: I. Response of growth, water relations, and ion accumulation to $\mathrm{NaCl}$ salinity. Crop Physiology \& Metabolism. Crop Science Society of America. 44:797-805.677 S. Segoe Rd., Madison, WI 53711 USA. https:// doi.org/10.2135/cropsci2004.0797

Niu, G.H., W.W. Xu, D.S. Rodriguez and Y.P. Sun. 2012. Growth and physiological responses of maize and sorghum genotypes to salt stress. ISRN Agronomy, 2012 (Article ID 145072). https://doi.org/10.5402/2012/145072

Olanite, J. A., U.Y. Anele, O.M. Arigbede, A.O.
Jolaosho and O.S. Onifade. 2010. Effect of plant spacing and nitrogen fertilizer levels on the growth, dry-matter yield and nutritive quality of Columbus grass (Sorghum almum stapf) in southwest Nigeria. Grass Forage Sci., 65(4): 369375 .https://doi.org/10.1111/j.13652494.2010.00755.x

Omer, M.Z.E.G. and H.A. Abdelwahab. 2016. The effect of salt concentration on growth and yield of two forage sorghum (Sorghum bicolor (L.) Moench) Lines. Agric. Forestry and Fisheries, 5(6): 280-284. https://doi.org/10.11648/j. aff.20160506.20

Qadar, A. 2009. Alleviation of salt stress through nutrient management. In: Enhancing Nutrient Use Efficiency in Problem Soils (Eds. Singh, G., Qadar, A., Yaduvanshi, N.P.S. and Dey, P.). Central Soil Salinity Research Institute, Karnal, India, pp132-157.

Qu,H.,X.B.Liu,C.F.Dong,X.Y.Lu and Y.X.Shen. 2014. Field performance and nutritive value of sweet sorghum in eastern China. Field Crops Res., 157: 84-88. https://doi.org/10.1016/j. fcr.2013.12.010

Qureshi, A.S. 2020. Groundwater governance in Pakistan: from colossal development to neglected management. Water, 12 :2-19. https://doi.org/10.3390/w12113017

Rady, M.M., T.A. Abd El-Mageed, H.A. Abdurrahman and A.H. Mahdi. 2015. Humic acid application improves field performance of cotton (Gossypium barbadense L.) under saline conditions. J. Anim. Plant Sci., 26(2): 487-493.

Saberi, A. 2013. Biochemical composition of forage sorghum (Sorghum bicolor L.) varieties under influenced of salinity and irrigation frequency. Int. J. Traditional and Herbal Med., 1 (2): 2837.

Sánchez-Duarte, J.I., K.F. Kalscheur, A.D. García and F.E. Contreras-Govea. 2018. Short communication: Meta-analysis of dairy cows fed conventional sorghum or corn silages compared with brown midrib sorghum silage. J. Dairy Sci., 102(1): 419-425. https://doi. org/10.3168/jds.2018-14552

Saqib, A.I., A. Khalil, R.N. Abdul, Q. Ghulam, Q.N. Muhammad, M. Zaheen and I. Muhammad. 2018. Effect of brackish water on the production of garlic and soil properties. Int. J. Biosci., 12: 174-182.

Semida, W.M., T.A. Abd El-Mageed, E.M. Sabry 
and A.E. Nevein, 2017. Combined effect of deficit irrigation and foliar applied salicylic acid on physiological responses, yield, and water use efficiency of onion plants in saline calcareous soil. Arch. Agron. Soil Sci., 63: 1227-1239.

Shakeri, E. and Y. Emam. 2017. Selectable traits in sorghum genotypes for tolerance to salinity stress. J. Agric. Sci. Tech., 19:1319-1332.

Soni, P.G., R.K. Yadav, A. Kumar, G. Yadav, G. Kumar and T. Yadav. 2016. Effect of domestic wastewater and irrigation schedules on quality of fodder sorghum. J. Soil Salinity Water Quality, 8(2): 173-179.

Steel R.G.D., J.H. Torrie and D.A. Dickey. 1997. Principles and Procedures of Statistic: A Biometrical Approach. $3^{\text {rd }}$ edition, pp: 400-428. Mc Graw Hill Book Co. Inc. New York, USA.

Sui, N., Z. Yang, M. Liu and B. Wang, B. 2015. Identification and transcriptomic profiling of genes involved in increasing sugar content during salt stress in sweet sorghum leaves. BMC Genomics, 16: 534. https://doi.org/10.1186/ s12864-015-1760-5

Sun, Y., G. Niu, P. Osuna, L. Zhao, G. Ganjegunte, G. Peterson, J.R.P. Videa and J.L.G. Torresdey. 2014. Variability in Salt Tolerance of Sorghum bicolor L. Agric. Sci., 2(1): 09-21.

Tandon, H.L.S. 2005. Methods of analysis of soils, plants, waters, fertilizers and organic manures. New Delhi: Fertilizer Development and Consultation Organization.

Tigabu, E., M. Andargie and K. Tesfaye. 2013. Genotypic variation for salinity tolerance in sorghum (Sorghum bicolor L.) Moench genotypes at early growth stages. J. Stress Physiol. Biochem., 9: 253-262.

US Salinity Laboratory Staff .1954. Diagnosis and Improvement of Saline and Alkali Soils. USDA Handbook 60, Washington, DC, USA.

Yan, K., P. Chen, H. Shao, S. Zhao, L. Zhang, G. $\mathrm{Xu}, \mathrm{J}$. Sun. 2012. Responses of photosynthesis and photosystem II to higher temperature and salt stress in Sorghum. J. Agron. Crop Sci., 198(3): 218-225. https://doi.org/10.1111/ j.1439-037X.2011.00498.x

Yang, Z., H. Zheng, X. Wei, J. Song, B. Wang and N. Sui. 2018. Transcriptome analysis of sweet Sorghum inbred lines differing in salt tolerance provides novel insights into salt exclusion by roots. Plant Soil, 430: 423-439. https://doi. org/10.1007/s11104-018-3736-0 